\title{
Приповерхностные субмикроструктуры для эффективного детектирования и генерации гармоник излучения среднего ИК-диапазона
}

\author{
В.П. Назьмов ${ }^{1)}$, Б.Г. Гольденберг ${ }^{1)}$, В.Е. Асадчиков ${ }^{2)}$, С.А. Бедин ${ }^{2)}$, А.Б. Васильев ${ }^{2)}$, А.В. Андреев ${ }^{3)}$, \\ В.М. Гордиенко ${ }^{3)}$, А.А. Коновко ${ }^{3)}$, Ф.В. Потемкин ${ }^{3)}$ \\ ${ }^{1}$ Институт ядерной физики им. Г.И. Будкера Сибирского отделения Российской академии наук, \\ 630090 Новосибирск, проспект Академика Лаврентьева, д. 11 \\ ${ }^{2}$ Федеральный научно-исследовательский центр «Кристаллография и фотоника» Российской \\ академии наук, 119333, г. Москва, Ленинский проспект, д. 59 \\ ${ }^{3}$ Московский государственный университет имени М.В.Ломоносова, Физический факультет \\ 119991, ГСП-1, Москва, Ленинские горы, д. 1, стр. 2 \\ тел:+7 (913) 376-6033, факс:+7 (812) 247-1017, эл.nочта: vovochkaprim@mail.ru
}

DOI 10.34077/RCSP2019-18

Разработан метод формирования регулярных металлических, диэлектрических и композитных микроструктур на основе пленок полиэтилентерефталата, облученных на источнике синхротронного излучения через маску, с последующим травлением. Для исследования геометрических параметров синтезированных структур использована растровая электронная микроскопия.

Регулярные ориентированные металлические, диэлектрические и композитные микро- и наноструктуры представляют значительный интерес в качестве элементов устройств управления оптическим излучением в том числе для создания перспективных фотоприемников ИК-диапазона и хранения информации [1]. Такие структуры можно получить в результате синтеза с использованием в качестве несущих элементов предварительно подготовленных полимерных пленок, в которых созданы каналы, задающие морфологические характеристики синтезируемой структуры. Указанные каналы создаются в результате облучения пленки на циклотроне тяжелыми ионами или на синхротроне жестким рентгеновским излучением через маску с калиброванными отверстиями с последующим травлением [2]. Идентичность и регулярность размеров создаваемых в плёнках микроструктур является важным критерием возможности их практического применения. Развитый метод синтеза позволяет создавать периодические поверхностные микро и наноструктуры на площадях размеров порядка десятков квадратных сантиметров.

Полученные в работе результаты могут быть применены при создании оптических элементов с селективными свойствами, например, двумерных фотонных кристаллов, плазмонных антенных решеток, элементов для фотоприемников ИК-диапазона. Микроструктуры из металлов или нелинейных диэлектриков типа фазированной антенной решетки позволяют значительно увеличить сигнал второй гармоники по сравнению с генерацией в однородном объеме, что существенно расширяет возможности регистрации излучения за счет преобразования его частоты [3-5].

Работа выполнена при поддержке Министерства науки и высшего образования в рамках выполнения работ по Государственному заданию ФНИЦ «Кристаллография и фотоника» РАН в части выращивания диэлектрических и металлических микрокристаллов и Гранта РФФИ 18-29-20090 в части получения регулярных мембран и рассмотрению возможности их применимости для решения задач фотоники.

\section{Лuтература}

[1] В.Г. Семенов, С.А. Бедин, В.Е. Асадчиков, А.Б. Васильев // Письма в ЖТФ. 2018 Т. 44. № 14. С. 66-72.

[2] Goldenberg B.G., Lemzyakov A.G., Nazmov V.P., Pindyurin V.F. // Physics Procedia, 2016, v.84, p.205.

[3] Гапоненко С. В. И др. // Оптика наноструктур. СПб «Недра», 2005 г. - 326с.

[4] А.Э. Муслимов, А.В. Буташин, Б.В. Набатов, А.А. Коновко, И.В. Белов, Р.М. Гизетдинов, А.В.

Андреев, В.М. Каневский. // Кристаллография. 2017. Т. 62, № 2. С. 281-290.

[5] E. A. Migal, F. V. Potemkin, and V. M. Gordienko. // Optics letters 42.24 (2017): 5218-5221. 